\title{
Evaluation of IL-6 and IL-8 in Tear Fluid of Sulfur Mustard Gas-Exposed Patients with Eye Lesions
}

\author{
Reza Hajihosseini' ${ }^{1}$, Majid Shohrati², Mostafa Naderi², Nilofar Azimi', \\ Mallek Astar Esfandiari², Bita Najafian² \\ ${ }^{1}$ University of Medical Science of Baghiyatallah, Tehran, Iran \\ ${ }^{2}$ Payame Noor University, Tehran, Iran \\ Email: reza hajihosseini@yahoo.com
}

Received 23 June 2014; revised 25 July 2014; accepted 19 August 2014

Copyright (C) 2014 by authors and Scientific Research Publishing Inc.

This work is licensed under the Creative Commons Attribution International License (CC BY). http://creativecommons.org/licenses/by/4.0/

(c) (i) Open Access

\section{Abstract}

The purpose of this study is to compare the levels of IL-6, 8 in tear fluids of people exposed to mustard gas in the war between Iraq and Iran who had the chronic dry-eye symptoms compared to the normal group. In this study, 25 of the patients who were exposed to mustard gas and had chronic dry eye symptoms were compared to 25 patients as control group, consisting of 25 people who had common chronic dry eye symptoms with blepharitis and 25 healthy people as normal group. The levels of IL-6 and IL-8 in tear fluid of people of these three groups were assessed by enzyme-linked immunosorbent assay (ELISA). The results for levels of IL-6 $(P=0.002)$ and IL-8 $(P$ $=0.001$ ) in tear fluid of patients in comparison with normal group show a significant increase. The differences were considered statistically significant at $P<0.05$. The effect of exposure to mustard gas on eyes of chemical-injured veterans destroyed meibomian glands which paved the way for evaporative type of dry-eye. As a result, the cited ILs in the tear fluid of these patients increased and resulted in later eye-impairments.

\section{Keywords}

Sulfur Mustard Gas, Inflammatory Cytokines, Enzyme-Linked Immunosorbent Assay (ELISA)

\section{Introduction}

Mustard gas (bis (2-chloroethyl)sulphide), is from vesicant alkylating material which has been used as a chemical weapon so far [1]-[4]. 
The mustard in gas or in liquid, reacts on skin, eye, lung and gastrointestinal system and because of its high solubility in lipid (fat), it can be easily absorbed by skin and then internal organs, and result in damages to lung and gastrointestinal system [5] [6]. Among these damages the blood making system is the most important one which is being affected and the symptoms are divided in early and late stages [7]-[9].

The most sensitive organ to mustard is eye, which is affected quickly. First there is commonly a feeling of external object with progressive pain and redness in the eye, afterwards edema and acute symptoms appear and extreme pain and temporary blindness will arise in case of excessive exposure. In examination, belpharospasm, edema around eye and anterior chamber inflammation have been observed [10], in a way that surface epithelium will separate within several hours followed by vision reduction. And in case of higher exposure it may lead to corneal ulceration and permanent blindness [11]. The improvements start in the next 48 hours and usually within 5 days corneal epithelium forms and through 6 months it will be completed [12].

Studies on victims exposed to SM in Iran-Iraq war show eye-lesions, dry eye, MGD (Meibomian Gland Dysfunction) and blepharitis. Dry eye disease is a disorder caused by lack of tear or over-evaporation of tear which damage the internal eye surface and is accompanied by eye tenderness [13]. There are so many increasing evidences to prove the relationship between eye surface inflammation and dry eye.

Studies depict an increase in inflammatory cytokine (Interleukin-6, 8) levels in tear film [14] [15].

According to the Dr. qasemi [16] and his colleague's study on SM exposed eye lesions, dry eye, belepharitis, corneal ulceration and MGD in most chemical victims have been observed, which made us measure the amount of inflammatory cytokines (IL-6, IL-8) to look for the effectiveness of these factors on the chemical victims eye lesions.

\section{Methodology}

Ethical approval (Appendix) was sought and approved by the Ethical Committee of the Faculty/Institute Research Committee, Payame Noor University. This study is performed in Baqiyatallah Hospital, Tehran, Iran, in 2012. Our community contains 75 men including three groups; Group 1 containing 25 healthy subjects as normal group (Mean age $52.94 \pm 3.31$ ), Group 2 including 25 patients with common dry-eye accompanied by blepharitis as control group (Mean age $51.16 \pm 2.89$ ), and Group 3 which includes 25 patients who were last exposed at least 22 years ago and had chronic dry eye with blepharitis as patient group (Mean age $52.27 \pm 3.37$ years) with $P>0.05$ between the ages of three groups.

\subsection{Inclusion Criteria}

The shared inclusion criteria for all groups were being male gender, and having almost the same age range and availability for future evaluation. For Group 2, all cases had dry-eye accompanied with blepharitis. For group three being a chemical exposed veteran who was last exposed at least 22 years ago, and having established SM-resulted in dry-eye (according to previous medical documents) accompanied with blepharitis were the inclusion factors. Besides that all groups were examined by an ophthalmologist to be diagnosed with dry-eye and blepharitis.

\subsection{Exclusion Criteria}

For either control or patient group any signs of infectious diseases, Sjögren's syndrome and Rheumatoid arthritis and other ocular surface diseases were our exclusion criteria.

\subsection{Tear Collection}

Tear fluid was collected from the inferior tear meniscus, causing the least irritation possible, using a preweighed surgical sponges. Sponges were then placed into the end of a micropipette tip located within a $0.5 \mathrm{ml}$ tube and the tear fluid was subsequently recovered by centrifugation at $8000 \times \mathrm{g}$ at $4^{\circ} \mathrm{C}$ for $15 \mathrm{~min}$. The tears used for protein quantification were immediately placed in ice $<1 \mathrm{~h}$ before freezing and stored at $-80^{\circ} \mathrm{C}$ until they were used for enzyme linked immunosorbent assay (ELISA) [17].

\subsection{Enzyme-Linked Immunosorbent Assay}

The tear samples were collected to measure the levels of pro-inflammatory molecules which were obtained from 
different patients with the same pathologies, but we used one ELISA kit per molecule. Double sandwich ELISAs for human IL-6, 8 were performed with commercial kits (BENDER MEDSYSTEMS) according to manufacturer's protocol.

\subsection{Assay Procedure}

All reagents and samples were brought to room temperature $\left(18^{\circ} \mathrm{C}\right.$ to $\left.25^{\circ} \mathrm{C}\right)$ before use. It is recommended that all standards and samples be run at least in duplicate. $100 \mu \mathrm{l}$ volume of each standard and sample and then $50 \mu 1$ of Biotin-Conjugate was added into appropriate wells. The wells were covered and incubated for $2 \mathrm{~h}$ at room temperature on a microplate shaker set at $400 \mathrm{rpm}$. The solution was discarded and washed 4 times with $1 \mathrm{x}$ wash solution. Washing was done by filling each well with wash buffer $(400 \mu \mathrm{l})$, using a multi-channel pipette or auto-washer. Complete removal of liquid at each step is essential to good performance. After the last wash, any remaining wash buffer was removed by aspirating or decanting. The plate and blot were inverted against clean paper towels. After that, $100 \mu \mathrm{l}$ of diluted Streptavidin-HRP were added to all wells, including the blank wells, incubated for $1 \mathrm{~h}$ at room temperature with gentle shaking and the solution discarded. The wash was repeated as in step 3. Later, $100 \mu \mathrm{l}$ of TMB Substrate Solution was added to all wells. The solution was incubated for $10 \mathrm{~min}$ at room temperature in the dark with gentle shaking. In the end, $100 \mu \mathrm{l}$ of stop solution was added to each well and read at $450 \mathrm{~nm}$ immediately.

\subsection{Statistical Analysis}

The Mann-Whitney U test was used for statistical comparisons between groups. Data are expressed as means \pm $\mathrm{SD}$ and the differences were considered statistically significant at $P<0.05$.

\section{Results}

In this study, the mean levels of IL-6, 8 in tear fluid of three pre-defined groups have been calculated and represented in Table 1. The mean levels of IL-6 in tear fluid of Group 3, chemical exposed veterans, (201.29 \pm $27.01 \mathrm{pg} / \mathrm{ml} ; P=0.002)$, and in Group 2, control group, $(198.78 \pm 3.98 \mathrm{pg} / \mathrm{ml} ; P=0.002)$ were calculated and were significantly higher in comparison with Group 1, normal control (134.84 $\pm 23.09 \mathrm{pg} / \mathrm{ml}$ ) (Figure 1). Also, there were significant differences in levels of IL-8 in tear fluid of Group $3(2000.08 \pm 11.07 \mathrm{pg} / \mathrm{ml} ; P=0.001)$ and Group 2 (1998.94 $\pm 11.52 \mathrm{ng} / \mathrm{ml} ; P=0.001)$ compared to Group 1 (4.33 $\pm 26.97 \mathrm{pg} / \mathrm{ml})$ (Figure 2).

\begin{tabular}{|c|c|c|c|}
\hline \multicolumn{4}{|c|}{ Concentration (pg/ml) } \\
\hline Groups & $\mathbf{N}$ & IL-6 & IL-8 \\
\hline 1. Normal group & 25 & $134.84 \pm 23.09$ & $1364.33 \pm 26.97$ \\
\hline $\begin{array}{l}\text { 2. Control group } \\
P^{*} \text { (Mann-Whitney U test) }\end{array}$ & 25 & $\begin{array}{c}198.78 \pm 3.98 \\
0.002\end{array}$ & $\begin{array}{c}1998.94 \pm 11.52 \\
0.001\end{array}$ \\
\hline $\begin{array}{l}\text { 3. Patients group } \\
P^{* *} \text { (Mann-Whitney U test) }\end{array}$ & 25 & $\begin{array}{c}201.29 \pm 27.01 \\
0.002\end{array}$ & $\begin{array}{c}2000.08 \pm 11.07 \\
0.001\end{array}$ \\
\hline
\end{tabular}

*comparing Group 2 with $1 ;{ }^{* *}$ comparing Group 3 with 1.

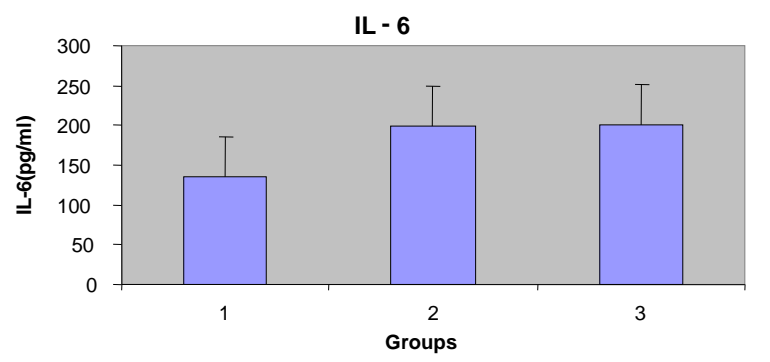

Figure 1. The mean levels of IL-6 in tear samples. Group 1 (normal group), Group 2 (control group; common dry-eye accompanied by blepharitis) and Group 3 (chemical exposed veterans). 


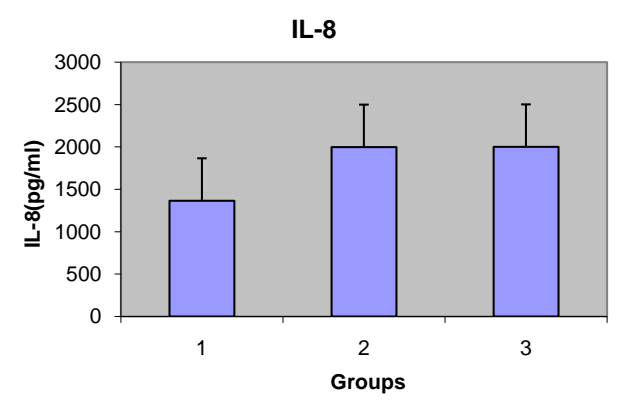

Figure 2. The mean levels of IL-8 in tear samples. Group 1 (normal group), Group 2 (control group; common dry-eye accompanied by blepharitis) and Group 3 (chemical exposed veterans).

\section{Discussion}

Dry eye is the late result of being exposed to mustard gas, which the chemically injured victims of Iran-Iraq war are suffering from. Besides, dry eye is one of the most distinguished complications in eye injuries in veterans. The main reason for dry eye in chemical veterans, whose meibomian glands were damaged, is the exposure to mustard gas and therefore primitive blepharitis due [16]. Meibomian glands damage (MGD) impedes lipid layer production, subsequently the amount of bipolar lipids especially sphingomyelin in tear fluid is reduced sharply [18] [19], which in turn, results in inflammatory stimulation of conjunctiva and generates the evaporative form of dry eye.

Arantxa Acera and the staff [20] have shown that the level of IL-6 and also matrix metalloproteinas-9 (MMP-9) which is a factor of inflammation in blepharitis victims, having problem in meibomian glands (MGD), shows a significant increase in contrast with the controlled group [21]. Morgan and colleague [13] have discovered a striking increase in amount of (IL-6, IL-8) in dry eye victims in comparison with control group.

Besides, gene expression increase for IL-6 and IL-8 in epithelium of conjunctivitis in dry eye victims has been reported [22] and now it's certain that conjunctivitis cells and lachrymal glands produce the cytokines secreted in tears [23]-[25].

In our study, we could find that the amount of IL-6 has a significant increase in dry eye group (Group 2) and also chemical victims with eye lesions (Group 3 ) than normal group (Group 1).

Pro-inflammatory cytokines (IL-6, IL-1 $\beta$, and TNF-a) showed a statistical increase in DED patients against control group. These cytokines have been reported to reduce tear production by the lachrymal gland via neuronal and hormonal effects [26]. Also they have shut down the nerve terminal and play a role in turning androgen into estrogen [26]. The increase in mRNA expression of these pro-inflammatory cytokines affects on conjunctiva to the same extent. In addition there is an increase in DED in contrast with normal controls as a rise in the same cytokine dose in tear concentration. This relationship can explains that conjunctiva, is primarily responsible for high expression of cytokines observed in DED patient's tears which may lead to lower tear production. IL-8 is a major cytokine which is smaller than others and has the characteristic of strong chemotactic in T-cells and multicore cells that is dramatically increased in dry eye patient's tears versus the control group. IL-8 amplification by resident tissues is an important mechanism for the leukocytes to move, especially in avascular tissues, like the cornea. High levels of IL-8 have been regarded as a pathogenic reason in human and in inflammatory diseases and intraocular inflammations [27] [28]. Therefore, increase in IL-8 in tear film of DED patients may be a signal for $\mathrm{T}$ lymphocytes to the ocular surface which may lead to damage the cornea and conjunctiva with usual signs of DED.

\section{Summary}

In summary, we found out that the eye surface changes in those who were exposed to SM (dry eye, blepharitis, corneal lesions) are in direct relation with inflammatory cytokine (IL-6, IL-8) in their tears. These results probably are the significant factor on chemical victims suffering. By new remedies, using cytokine suppressors, there may be a promising approach to help the chemical victims.

In the end, we believe in measuring other inflammatory factors in tears as a logical next step to open new ways of treating the veteran and all the others in need. 


\section{References}

[1] Mahmoudi, M., Hefazib, M., Rastina, M. and Balali-Mood, M. (2005) Long-Term Hematological Unological Complications of Sulfur Mustard Poisoning in Iranian Veterans. International Immunopharmacology, 5, 1479-1485. http://dx.doi.org/10.1016/j.intimp.2005.04.003

[2] Gosden, C.M. (2001) The 1988 Chemical Weapons Attack on Halabja, Iraq. In: Alexander, Y. and Hoening, M., Eds., Super Terrorism: Biological Weapons, Chemical and Nuclear, Transnational Publishers, Ardsley, 7-12.

[3] Dacre, J.C. and Goldman, M. (1996) Toxicology and Pharmacology of the Chemical Warfare Agent Sulfur Mustard. Pharmacological Reviews, 48, 289-326.

[4] Shohrati, M., Ghanei, M., Shamspour, N., Babaei, F., badi, M.N., et al. (2010) Glutathione and Malondialdehyde Levels in Late Pulmonary Complications of Sulfur Mustard Intoxication. Lung, 188, 77-83.

[5] Shohrati, M., Ghanei, M., Harandi, A.A., Foroghi, S. and Harandi, A.A. (2012) Effect of Nebulized Morphine on Dyspnea of Mustard Gas-Exposed Patients: A Double-Blind Randomized Clinical Trial Study. Pulmonary Medicine, 2012, Article ID: 610921, 6 p.

[6] Shohrati, M., Ghanei, M., Shamspour, N. and Jafari, M. (2008) Activity and Function in Lung Injuries Due to Sulphur Mustard. Biomarkers, 13, 728-733.

[7] Maynard, R.L., Meredith, T.J., Marrs, T.C. and Vale, J.A. (1991) Management of War Injuries. The Lancet, 337, 122.

[8] Balali-Mood, M. and Hefazi, M. (2006) Comparison of Early and Late Toxic Effects of Sulfur Mustard in Iranian Veterans. Basic \& Clinical Pharmacology \& Toxicology, 99, 273-282. http://dx.doi.org/10.1111/j.1742-7843.2006.pto_429.x

[9] Khaheshi, I., Keshavarz, S., Ali Imani Fooladi, A., Ebrahimi, M., Yazdani, S., et al. (2011) Loss of Expression of TGF-bs and Their Receptors in Chronic Skin Lesions Induced by Sulfur Mustard as Compared with Chronic Contact Dermatitis Patients. BMC Dermatology, 11, 2.

[10] Geeraets, W.J., Abedi, S. and Blanke, R.V. (1977) Acute Corneal Injury by Mustard Gas. Southern Medical Journal, 70, 348-351. http://dx.doi.org/10.1097/00007611-197703000-00028

[11] Dahl, H., Gluud, B., Vangested, P. and Norn, M. (1985) Eye Lesions Induced by Mustard Gas. Acta Ophthalmologica, 173, S30-S31.

[12] Mann, I., Pirie, A. and Pullinger, B.D. (1948) An Experimental and Clinical Study of the Reaction of the Anterior Segment of the Eye to Chemical Injury, with Special References to Chemical Warfare Agents. British Journal of Ophthalmology, Monograph Supplement XIII.

[13] Massingale, M.L., Li, X., Vallabhajosyula, M., Chen, D., Wei, Y. and Asbell, P.A. (2009) Analysis of Inflammatory Cytokines in the Tears of Dry Eye Patients. Cornea, 28, 1023-1027.

[14] Stern, M.E., Gao, J., Schwalb, T.A., Ngo, M., Tieu, D.D., Chan, C.C., Reis, B.L., Whitcup, S.M., Thompson, D. and Smith, J.A. (2002) Conjunctival T-Cell Subpopulations in Sjogren's and Non-Sjogren's Patients with Dry Eye. Investigative Ophthalmology \& Visual Science, 43, 2609-2614.

[15] Rolando, M., Barabino, S., Mingari, C., Moretti, S., Giuffrida, S. and Calabria, G. (2005) Distribution of Conjunctival HLA-DR Expression and the Pathogenesis of Damage in Early Dry Eye. Cornea, 24, 951-954. http://dx.doi.org/10.1097/01.ico.0000157421.93522.00

[16] Ghasemi, H., Ghazanfari, T., Ghassemi-Broumand, M., Javadi, M.A., Babaei, M., Soroush, M.R., et al. (2009) LongTerm Ocular Consequences of Sulfur Mustard in Seriously Eye Injured War Veterans. Cutaneous and Ocular Toxicology, 28, 71-77. http://dx.doi.org/10.1080/15569520902913936

[17] Hosseini, R.H. and Esfandiary, M.A. (2012) Levels of Matrix Metalloproteinases (MMPs) in Tear Fluid of Mustard Gas Exposed Patients with Chronic Dry-Eye Symptoms. African Journal of Biochemistry Research, 6, 55-61.

[18] McCully, J.P. and Shine, W. (1997) A Compositional Based Model for the Tear Film Lipid Layer. Transactions of the American Ophthalmological Society, 95, 79-88.

[19] McCully, J.P. and Shine, W. (2002) Meibomian Gland and Tear Film Lipids: Structure, Function and Control, Lacrimal Gland, Tear Film, and Dry Eye Syndromes. Advances in Experimental Medicine and Biology, 506, 373-378.

[20] Acera, A., Rocha, G., Vecino, E., Lema, I. and Durán, J.A. (2008) Inflammatory Markers in the Tears of Patients with Ocular Surface Disease. Ophthalmic Research, 40, 315-321. http://dx.doi.org/10.1159/000150445

[21] Afonso, A.A., Sobrin, L., Monroy, D.C., Selzer, M., Lokeshwar, B. and Pflugfelder, S.C. (1999) Tear Fluid Gelatinase B Activity Correlates with IL-1 $\alpha$ Concentration and Fluorescein Clearance in Ocular Rosacea. Investigative Ophthalmology \& Visual Science, 40, 2506-2512.

[22] Solomon, A., Dursun, D., Liu, Z., Xie, Y., Macri, A. and Pflugfelder, S.C. (2001) Pro- and Anti-Inflammatory Forms of Interleukin-1 in the Tear Fluid and Conjunctiva of Patients with Dry-Eye Disease. Investigative Ophthalmology \& 
Visual Science, 42, 2283-2292.

[23] Luo, L., Li, D.Q., Doshi, A., Farley, W., Corrales, R.M. and Pflugfelder, S.C. (2004) Experimental Dry Eye Stimulates Production of Inflammatory Cytokines and MMP-9 and Activates MAPK Signaling Pathways on the Ocular Surface. Investigative Ophthalmology \& Visual Science, 45, 4293-4301. http://dx.doi.org/10.1167/iovs.03-1145

[24] Trousdale, M.D., Zhu, Z., Stevenson, D., Schechter, J.E., Ritter, T. and Mircheff, A.K. (2005) Expression of TNF Inhibitor Gene in the Lacrimal Gland Promotes Recovery of Tear Production and Tear Stability and Reduced Immunopathology in Rabbits with Induced Autoimmune Dacryoadenitis. Journal of Autoimmune Diseases, 2, 6. http://dx.doi.org/10.1186/1740-2557-2-6

[25] Zhu, Z., Stevenson, D., Schechter, J.E., Mircheff, A.K., Ritter, T., Labree, L. and Trousdale, M.D. (2004) Prophylactic Effect of IL-10 Gene Transfer on Induced Autoimmune Dacryoadenitis. Investigative Ophthalmology \& Visual Science, 45, 1375-1381. http://dx.doi.org/10.1167/iovs.03-0755

[26] Zoukhri, D., Hodges, R.R., Byon, D. and Kublin, C.L. (2002) Role of Proinflammatory Cytokines in the Impaired Lacrimation Associated with Autoimmune Xerophthalmia. Investigative Ophthalmology \& Visual Science, 43, 14291436.

[27] Lee, E.B., Kim, J.Y., Zhao, J., Park, M.H. and Song, Y.W. (2007) Haplotype Association of IL-8 Gene with Behcet’s Disease. Tissue Antigens, 69, 128-132. http://dx.doi.org/10.1111/j.1399-0039.2006.00736.x

[28] Belguendouz, H., Messaoudene, D., Hartani, D., Chachoua, L., Ahmedi, M.L., Lahmar-Belguendouz, K., LahlouBoukoffa, O. and Touil-Boukoffa, C. (2008) Effect of Corticotherapy on Interleukin-8 and -12 and Nitric Oxide Production during Behcxet and Idiopathic Uveitis. Journal Français d'Ophtalmologie, 31, 387-395. http://dx.doi.org/10.1016/S0181-5512(08)71433-5 
Scientific Research Publishing (SCIRP) is one of the largest Open Access journal publishers. It is currently publishing more than 200 open access, online, peer-reviewed journals covering a wide range of academic disciplines. SCIRP serves the worldwide academic communities and contributes to the progress and application of science with its publication.

Other selected journals from SCIRP are listed as below. Submit your manuscript to us via either submit@scirp.org or Online Submission Portal.
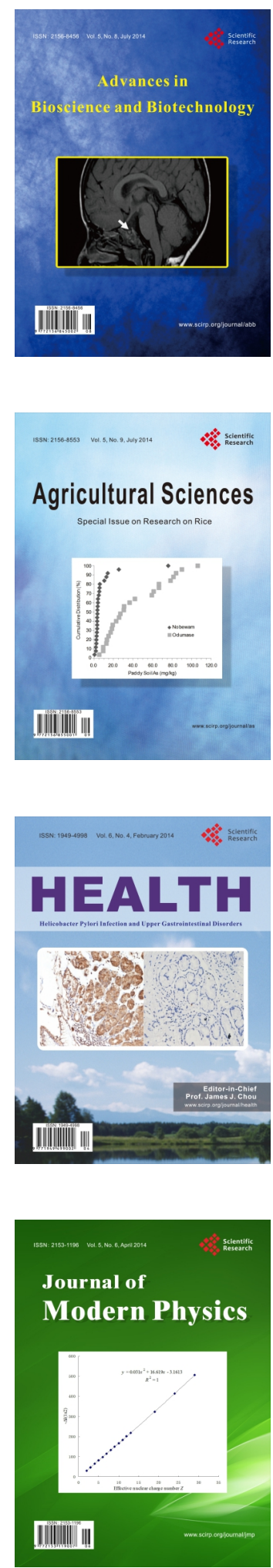
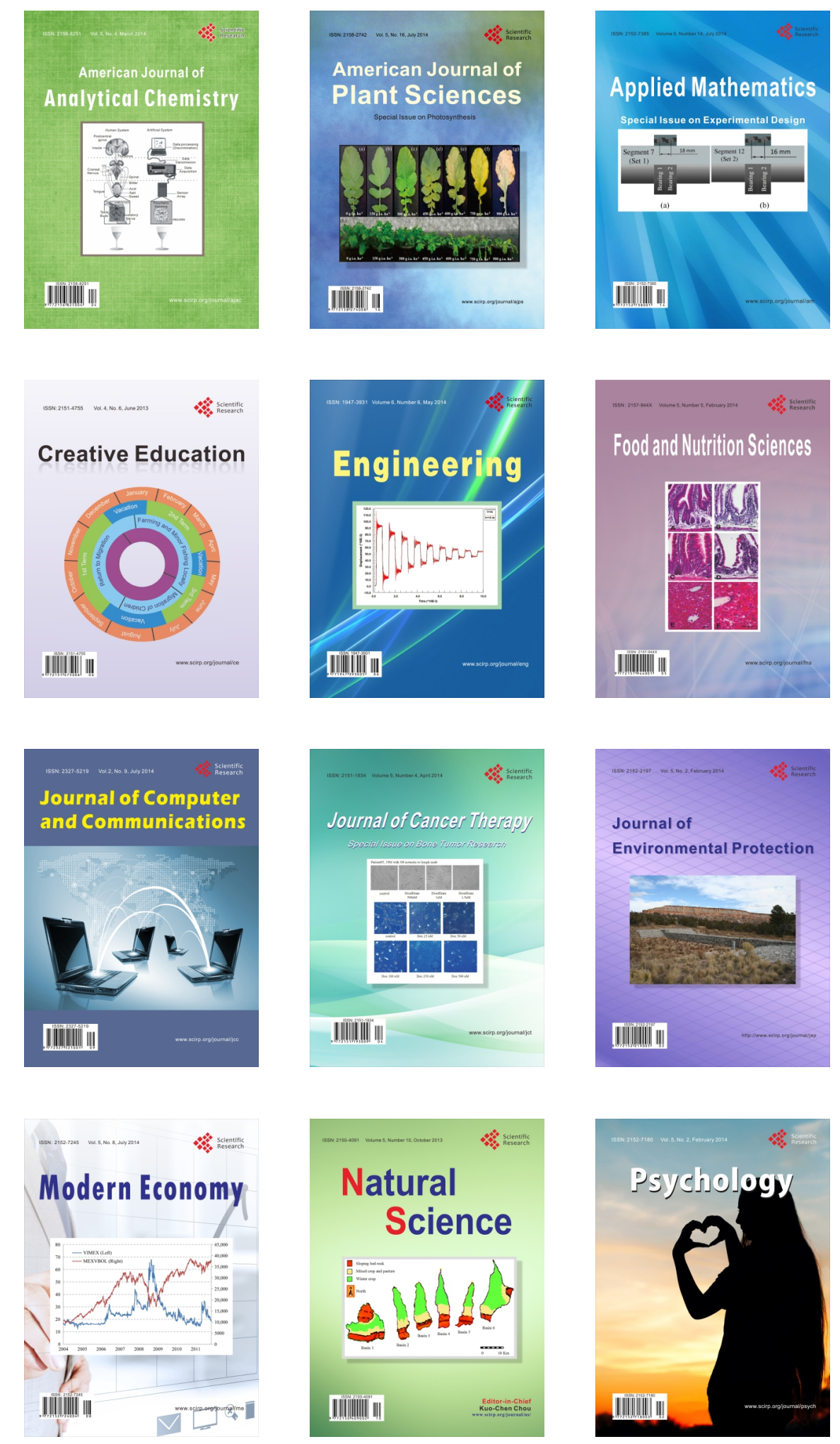